Fixed Point Theory, 22(2021), No. 2, 795-808

DOI: $10.24193 /$ fpt-ro.2021.2.52

http://www.math.ubbcluj.ro/ nodeacj/sfptcj.html

\title{
SOME VARIANTS OF FIBRE CONTRACTION PRINCIPLE AND APPLICATIONS: FROM EXISTENCE TO THE CONVERGENCE OF SUCCESSIVE APPROXIMATIONS
}

\author{
ADRIAN PETRUŞEL*, IOAN A. RUS** AND MARCEL-ADRIAN ŞERBAN** \\ *Department of Mathematics, Babeş-Bolyai University, Cluj-Napoca \\ and \\ Academy of Romanian Scientists Bucharest, Romania \\ E-mail: petrusel@math.ubbcluj.ro \\ ** Department of Mathematics, Babeş-Bolyai University, Cluj-Napoca, Romania \\ E-mail: iarus@math.ubbcluj.ro mserban@math.ubbcluj.ro
}

\begin{abstract}
Let $\left(X_{1}, \rightarrow\right)$ and $\left(X_{2}, \hookrightarrow\right)$ be two $L$-spaces, $U$ be a nonempty subset of $X_{1} \times X_{2}$ such that $U_{x_{1}}:=\left\{x_{2} \in X_{2} \mid\left(x_{1}, x_{2}\right) \in U\right\}$ is nonempty, for each $x_{1} \in X_{1}$. Let $T_{1}: X_{1} \rightarrow X_{1}, T_{2}: U \rightarrow X_{2}$ be two operators and $T: U \rightarrow X_{1} \times X_{2}$ defined by $T\left(x_{1}, x_{2}\right):=\left(T_{1}\left(x_{1}\right), T_{2}\left(x_{1}, x_{2}\right)\right)$. If we suppose that $T(U) \subset U, F_{T_{1}} \neq \emptyset$ and $F_{T_{2}\left(x_{1}, \cdot\right)} \neq \emptyset$ for each $x_{1} \in X_{1}$, the problem is in which additional conditions $T$ is a weakly Picard operator? In this paper we study this problem in the case when the convergence structures on $X_{1}$ and $X_{2}$ are defined by metrics. Some applications to the fixed point equations on spaces of continuous functions are also given.
\end{abstract}

Key Words and Phrases: Triangular operator, fibre contraction, weakly Picard operator, generalized metric space, generalized contraction, well-posedness, Ostrowki property, Ulam-Hyers stability, Volterra operator, functional differential equation, functional integral equation.

2020 Mathematics Subject Classification: 47H10, 54H25, 47H09, 45N05, 34K28.

\section{REFERENCES}

[1] S. András, Fibre $\varphi$-contraction on generalized metric spaces and applications, Mathematica, 45(68)(2003), no. 1, 3-8.

[2] C. Bacoţiu, Fibre Picard operators on generalized metric spaces, Sem. Fixed Point Theory Cluj-Napoca, 1(2000), 5-8.

[3] D.D. Bainov, S.G. Hristova, Differential Equations with Maxima, CRC Press, 2011.

[4] L. Barreira, C. Valls, Parameter dependence of stable manifolds for difference equations, Nonlinearity, 23(2010), no. 2, 341-367.

[5] A.M. Bica, S. Mureşan, G. Grebenişan, Parameter dependence of the solution of second order nonlinear ODE's via Perov's fixed point theorem, Aust. J. Math. Anal. Appl., 3(2006), no. 1, Art. 10, 8 pp.

[6] T.A. Burton, Stability by Fixed Point Theory for Functional Differential Equations, Dover Publ. New York, 2006.

[7] M.M. Deza, E. Deza, Encyclopedia of Distances, Springer, 2009.

[8] M. Dobriţoiu, W.W. Kecs, A. Toma, An application of the fiber generalized contractions theorem, WSEAS Trans. Math., 5(2006), no. 12, 1330-1335. 
[9] M. Dobriţoiu, M.-A. Şerban, Step method for a system of integral equations from biomathematics, Appl. Math. Comput., 227(2014), 412-421.

[10] W.M. Hirsch, C.C. Pugh, Stable manofolds and hyperbolic sets, Proc. Symp. in Pure Math., 14(1970), 133-163.

[11] V. Ilea, D. Otrocol, I.A. Rus, M.A. Şerban, Applications of fibre contraction principle to some classes of functional integral equations, to appear.

[12] V. Ilea, D. Otrocol, M.-A. Şerban, D. Trif, Integro-differential equations with two times lags, Fixed Point Theory, 13(2012), no. 1, 85-97.

[13] V. Mureşan, Existence, uniqueness and data dependence for the solution of a Fredholm integral equation with linear modification of the argument, Acta Sci. Math. (Szeged), 68(2002), no. 1-2, $117-124$.

[14] V. Mureşan, Existence, uniqueness and data dependence results for the solution of a VolterraSobolev functional-integral equation, Automat. Comput. Appl. Math. 19(2010), no. 2, 343-350.

[15] V. Mureşan, On a functional-differential equation, in: Fixed Point Theory and its Applications, (Eds. R. Espínola, A. Petruşel and S. Prus), House of the Book of Science, Cluj-Napoca, 2013, 201-207 pp.

[16] I.M. Olaru, An integral equation related to some epidemic model, Automat. Comput. Appl. Math., 19(2010), no. 2, 367-374.

[17] D. Otrocol, Smooth dependence on parameters for some Lotka-Volterra system with delays, An. Univ. Vest Timiş. Ser. Mat.-Inform., 43(2005), no. 1, 109-114.

[18] D. Otrocol, M.A. Şerban, An efficient step method for a system of differential equations with delay, J. Appl. Anal. Comput., 8(2018), no. 2, 498-508.

[19] A. Petruşel, G. Petruşel, A study of a general system of operator equations in b-metric spaces via the vector approach in fixed point theory, J. Fixed Point Theory Appl., 19(2017), 1793-1814.

[20] A. Petruşel, G. Petruşel, Coupled fixed points and coupled coincidence points via fixed point theory, in: Mathematical Analysis and Applications, Book Editors: M. Ruzhansky, H. Dutta, R.P. Agarwal, Wiley, 2018, pp. 661-717.

[21] A. Petruşel, I.A. Rus, Fixed point equations with abstract Volterra operators on spaces of functions of several variables, to appear.

[22] A. Petruşel, I.A. Rus, M.A. Şerban, Fixed points for operators on generalized metric spaces, CUBO A Mathematical Journal, 10(2008), no. 4, 45-66.

[23] I.A. Rus, A fibre generalized contraction theorem and applications, Mathematica, 41(1999), no. $1,85-90$.

[24] I.A. Rus, Fibre Picard operators and applications, Stud. Univ. Babeş-Bolyai Math., 44(1999), 89-98.

[25] I.A. Rus, Fibre Picard operators on generalized metric spaces and applications, Scripta Sc. Math., 1(1999), 326-334.

[26] I.A. Rus, Generalized Contractions and Applications, Cluj University Press Cluj-Napoca, 2001.

[27] I.A. Rus, Picard operators and applications, Sci. Math. Japonica, 58(2003), 191-219.

[28] I.A. Rus, Abstract models of step method which imply the convergence of successive approximations, Fixed Point Theory, 9(2008), 293-307.

[29] I.A. Rus, Some nonlinear functional differential and integral equations via weakly Picard operator theory: a survey, Carpathian J. Math., 26(2010), 230-258.

[30] I.A. Rus, Some variants of contraction principle, generalizations and applications, Stud. Univ. Babeş-Bolyai Math., 61(2016), no. 3, 343-358.

[31] I.A. Rus, Some variants of contraction principle in the case of operators with Volterra property: step by step contraction principle, Adv. Theory of Nonlinear Anal. Appl., 3(2019), 111-120.

[32] I.A. Rus, A. Petruşel, G. Petruşel, Fixed Point Theory, Cluj Univ. Press, Cluj-Napoca, 2008.

[33] I.A. Rus, A. Petruşel, M.A. Şerban, Fibre Picard operators on gauge spaces and applications, Zeitschrift für Analysis und ihre Anwendungen, 27(2008), 399-415.

[34] I.A. Rus, M.A. Şerban, Operators on infinite dimensional Cartesian product, An. Univ. Vest Timiş. Ser. Mat.-Inform., 48(2010), no. 1-2, 253-263. 
[35] I.A. Rus, M.A. Şerban, Some generalizations of a Cauchy lemma and applications, Topics in Mathematics, Computer Science and Philosophy, Editor Şt. Cobzaş, Cluj University Press, 2008, 173-181.

[36] I.A. Rus, M.A. Şerban, D. Trif, Step method for some integral equations from biomathematics, Bull. Math. Soc. Sci. Math. Roumanie, 54(102)(2011), no. 2, 167-183.

[37] J. Sotomayor, Smooth dependence of solutions of differential equations on initial data: a simple proof, Bol. Soc. Bras. Mat., 4(1973), 55-59.

[38] M.A. Şerban, Application of fiber Picard operators to integral equations, Bul. Ştiinţ. Univ. Baia Mare, Ser. B, Matematică-Informatică, 43(2002), no. 1, 119-128.

[39] M.A. Şerban, Fibre contraction theorem in generalized metric spaces, Automat. Comput. Appl. Math., 16(2007), no. 1, 139-144.

[40] M.A. Şerban, Fibre $\varphi$-contractions, Stud. Univ. Babeş-Bolyai Math., 44(1999), no. 3, 99-108.

[41] M.A. Şerban, Saturated fibre contraction principle, Fixed Point Theory, 18(2017), no. 2, 729740 .

[42] M.A. Şerban, Fixed Point Theory for Operators on Cartesian Product, (Romanian), Cluj University Press, Cluj-Napoca, 2002.

[43] A. Tămăşan, Differentiability with respect to lag for nonlinear pantograph equations. Modern applied analysis (Ilieni, 1997), Pure Math. Appl., 9(1998), no. 1-2.

[44] A. Vanderbauwhede, Centre manifolds, normal forms and elementary bifurcations, Dynamics Reports, Vol. 2, 89-169, Dynam. Report. Ser. Dynam. Systems Appl., 2, Wiley, Chichester, 1989.

Received: January 7, 2020; Accepted: December 14, 2020. 